\title{
The Socio-economic Impacts of the COVID-19 Pandemic: A Review
}

\author{
D. N. Nayak, R. Kumar* and C. V. Savalia \\ Department of Veterinary Public Health and Epidemiology, College of Veterinary Science \& \\ Animal Husbandry, Navsari Agricultural University, Navsari-396 450. Gujarat, India \\ *Corresponding author
}

\section{A B S T R A C T}

\section{Keywords \\ COVID-19, Pandemic, Public health, Socio- economic, Impacts, Quarantine, Industry \\ Article Info \\ Accepted: 07 October 2020 Available Online: 10 November 2020}

The COVID-19 pandemic has tremendously given a huge shock on world economy. The prolonged lockdown in most of the countries lead to disruption of demand and supply chains. The pandemic not only resulted extraordinary burden on healthcare sector with abrupt spike in cases every passing day, but also caused deleterious social and psychological impacts on people especially those belonging to the economically deprived sections of society together with loss of lives and jobs. Governments, imposed restrictions like social distancing, complete travel bans and shutdown of different institutions in total, commercial offices and industries, worldwide. The need for medical supplies increased and countries were unable to cope with limited resources like protective wares for healthcare workers and corona warriors. Panic-buying and unnecessary huge stocking of essential commodities by people lead to their shortfall in the availability of market stores. This pandemic is likely to have a long term impact in the lives of people the world over in both as social and economical. The overall socioeconomic effects of COVID-19 on various aspects of the world economy have been summarized in this short review.

\section{Introduction}

The first case of Corona virus was reported in Wuhan, China (Huang et al., 2020) in the mid of December 2019. Within short time the virus spread to most of the countries of the world with surprise of doctors, scientists, public health personnel as well as the government functionaries. The unprecedented spread with a very high fatality rate in some countries has resulted in extreme public health measures including a total lockdown being adopted in many countries. Looking at the outbreak and rapid spread in numerous countries, World Health Organization (WHO) declared it a public health emergency of international concern on $30^{\text {th }}$ January 2020 (WHO, 2020b, WHO, 2020c). The lock-down in countries which contribute largely to the global economy lead to the halting of services and production, which resulted in a standstill in various supply chains and thus, affected the global economy brutally (Ebrahim et al., 2020). Educational institutions have been shut down. The uncertainty and postponement of examinations also stressed young minds (Roy et al., 2020). People who were quarantined had to deal with separation from family and sense of uncertainty (Chaterji and Chauhan, 2020). 


\section{Effects of quarantine}

During SARS it was seen that longer the duration of quarantine more the chances of patients as well as acquaintances exhibiting PTSD symptoms (Hawryluck et al., 2004). Bai et al., (2004) in a study, observed that health workers also suffered from fatigue, detachment, nervousness, irritability, sleeplessness, poor concentration, indecisiveness, deteriorating work performance and consideration of resignation. Behavioral changes such as evading crowded places and delayed return to normalcy after the quarantine period were also seen (Cava et al., 2005). Reynolds et al., (2009) mentioned that a person with a history of any form of psychiatric ailment was associated with the experience of anger and anxiety, following 4 to 6 months post quarantine period. Recent evidence suggests that individuals who are kept in isolation and quarantine, experienced significant distress expressed by anxiety, anger, confusion and post-traumatic stress symptoms (Brooks et al., 2020). When quarantined, the health care workers showed more severe symptoms of post-traumatic stress than general public. They experienced humiliation, loss of income and greater psychological impact (Chaterji and Chauhan, 2020). Increased anger, fright, frustration, vulnerability, seclusion, loneliness, unhappiness and concern was observed in the workers noted by Taylor et al., (2008). Health-care workers were in the illusion that they had contagious disease and they may infect others. Since the beginning of the corona virus pandemic the use of masks and sanitizers has increased (Feng et al., 2020) resulting in unavailability in the market. A shortage of personal protective equipment endangers health workers worldwide (WHO, 2020c). It is a major cause of concern among medical personnel especially in a densely populated country like India with lack a robust healthcare infrastructure. Despite numerous appeals by government, police and doctors, people ignore the importance of social distancing and basic hygiene measures. The psychological health issues are also expected to increase day by day during this pandemic (Roy et al., 2020)

\section{Impact on various sectors}

\section{Agriculture}

The COVID-19 outbreak which resulted in the shutting down of hotels, restaurants and food industries resulted in nearly $20 \%$ drop in demand of agricultural commodities. An array of protective measures imposed by countries all over the world had slowed down transportation of products resulting in pronounced implications on perishable commodities such as meat, fruits and vegetables. Panic buying further complicated shortages of various commodities as expressed by Nikola et al., (2020).

\section{Manufacturing industry}

The COVID-19 pandemic has slowed down the economy and disrupted businesses of all sectors round the world. The manufacturing of various commodities has slowed down with shut down of many small scale industries resulted in millions of jobs being lost implicating a financial burden on families of workers. The families with only single earning member suffered the great and have a very long lasting impact. Even in the factories where work resumed after lockdown, the number of workers in one shift has to be curtailed in order to follow social distancing rules due to which the output of goods forcibly reduced. Even many workers were unwilling to resume work due to the fear of contracting infection. The countries like India has experienced an unimaginable migrant crisis. Migrant workers and labourers left the cities due to uncertainty and disappointment 
of their future and returned to their home town with the hope of a better life. The losses in national and international trade, reduced cash flow in the market and slowdown in the revenue growth of many countries has led to contraction of the GDP especially of poor and developing countries. Many countries are already in a huge economic debt. The 'work from home' option is not viable in manufacturing industries. Many companies have made large number of layoffs resulting in job losses. Also less number of working staff lead to a disruption of supply chains (Nikola et al, 2020).

\section{Education}

Close to 900 million learners have been affected by the closure of educational institutions (UNESCO, 2020). In order to prevent spread and carriage of the virus to susceptible individuals, over 100 countries imposed a nationwide closure of educational facilities. Children from poor families are unable to avail free school meals.

Moreover, populations with a higher income and urban base have better access of technology for online education compared to lower income groups and those living in rural areas. Parents who have suffered job loss and pay cuts during this period have urged schools to forego the fees of their children. Apart from primary education, the pandemic has also impacted higher education (Nikola et al., 2020). In the United Kingdom as well as USA all non COVID research has been put on hold by the national funding agencies so that clinically trained staff provide their services at the frontline (DHSC and NIH, 2020).

\section{Healthcare}

The risk faced by health care workers is an extraordinary challenge for healthcare systems worldwide. Hence, testing for asymptomatic and frontline healthcare staff is vital (Tanne et al., 2020). High costs, shortages of protective equipment including N95 face masks, and low numbers of ICU beds and ventilators have ultimately undermined in the delivery of patients' care. Doctors and nurses who contracted the infection and even lost their lives while serving patients have resulted in increased burden on the other staff. With rapid tall of deaths is rapidly increasing the mortuaries as well as cremation centers are unable to deal with the sudden inflow of dead bodies, and hence in many instances dead bodies have been kept for days in hospital premises predicting the risk of infection to staff as well as other patients (Nikola et al., 2020).

\section{Pharmaceutical industry}

The worldwide supply contribution of major active pharmaceutical ingredients from US and India (18\%), China $(13 \%)$ and the European Union (26\%) has adversely affected. China is the leading exporter of medical devices $(39.3 \%)$ to the US. Due to the pandemic there has been a slowdown in production, restrictions in supply which lead to loss of revenue (COVID-19 USA, 2020). Conversely, companies engaged in vaccine development have opportunities and with USbased companies including Johnson \& Johnson, Vir Biotechnology, Novavax and Nano Viricides announcing collaborative plans to develop a viral vaccine (NIH, 2020).

\section{Hospitality, tourism and aviation}

The hotel, tourism and aviation were among most hard-hit industries with non-permanent workers facing potentially devastating hard ships, from jobs being lost, salaries cut or not paid to placing staff on furlough. Italy, a famous tourist destination saw record number of cases in the early days of the pandemic. The World Travel and Tourism Council has 
predicted job loss of 50 million in the global travel and tourism sector (World Economic Forum, 2020). The travel industry witnessed an exceptional wave of cancellations due to postponement or non-organization of largescale sports and tournaments, religious and cultural events. Globally, borders were closed and travel suspensions implemented on most of the places. Apart from these, people and small businesses that thrived on income from tourists like guides, local artists and crafts man, private transporters completely shut down placing them under a huge financial constrain.

In conclusion and perspective, more than the effect of disease on health, fears of recession and uncertain future cause more panic in the people. Hence, a strong political leadership with acumen for better policy making in healthcare and industry as well as schemes which benefit the economically vulnerable sections of the society need to be implemented in order to reduce the impact of this pandemic. Immediate relief measures and long term planning is required to pull nations out of the economic crisis. Encouraging new entrepreneurs to build robust and sustainable business models, which do not crash during such unpredictable disasters is also important. Above all helping the less fortunate around us to rebuild their lives by giving and sharing is of foremost importance as the sociopsychological impact of such disaster is far more than its economic impact.

\section{Acknowledgement}

The authors are grateful to acknowledge the support rendered by the Dean, Veterinary College and Director of Research \& Dean, PGS, Navsari Agricultural University, Navsari, Gujarat, India by providing necessary facilities and resources to write this review article.

\section{References}

Bai, Y., Lin, C. C., Lin, C. Y., Chen, J. Y., Chue, C. M., and Chou, P. 2004. Survey of stress reactions among health care workers involved with the SARS outbreak. Psychiatric Services, 55:10551057.

Brooks, S., Webster, R., Smith, L., Woodland, L., Wessely, S., Greenberg, N. and Rubin, G. 2020.The psychological impact of quarantine and how to reduce it: rapid review of the evidence. Lancet. 395:912920.

Cava, M.A., Fay, K.E., Beanlands, H.J., McCay, E.A., and Wignall, R. 2005. The experience of quarantine for individuals affected by SARS in Toronto. Public Health Nursing, 22:398 - 406.

Chatterje, K. and Chauhan, V.S. 2020. Epidemics, quarantine and mental health. Medical Journal Armed Forces India, 76(2): 125127.

COVID-19 USA, 2020. Coronavirus outbreak measures and effect on the US. Available from: https://www.pharmaceuticaltechnology.com/features/coronavirusaffected countries-usa-covid-19-measuresimpact pharma-hotel-tourism medical/. covid19. pdf? sfvrsn=96b04 adf_2.

Ebrahim, S.H., Ahmed, Q.A., Gozzer, E., Schlagenhauf, P. and Memish, Z.A. 2020. Covid-19 and community mitigation strategies in a pandemic. British Medical Journal, 368.

Feng, S., Shen, C., Xia, N., Song, W., Fan, M., Cowling, B.J., 2020. Rational use of face masks in the COVID-19 pandemic. Lancet Respiratory Medicine.

Hawryluck, L., Gold, W. L., Robinson, S., Pogorski, S., Galea, S. and Styra, R. 2004. SARS control and psychological effects of quarantine, Toronto, Canada. Emerging Infectious Diseases, 10:1206-1212.

Huang, C. Wang, Y., Li, X., Ren, L., Zhao, J. and Hu Y. 2020. Clinical features of patients infected with novel corona virus in Wuhan, China. Lancet, 395(10223):497506.

Nicola, M., Alsafi, Z. Sohrabi, C., Kerwan, A., Ahmed Al-Jabird, Iosifidis, C., Agha, M. 
and Agha, R. 2020. The socio-economic implications of the corona virus pandemic (COVID-19): A review. International Journal of Surgery, 78: 185-193.

NIH, 2020. NIH Clinical Trial of Investigational Vaccine for COVID-19 begins, Available from: $\quad$ https://www.nih.gov/newsevents/news-releases/nih-clinicaltrialinvestigational-vaccine- covid-19begins.

NIH, 2020. NIH Shifts Non-mission-critical Laboratory Operations to Minimal Maintenance Phase, National Institutes of Health (NIH), Available from: https://www.nih.gov/news-events/newsreleases/nih-shiftsnon-mission-criticallaboratoryoperations-minimalmaintenance- phase.

NIHR, 2020. DHSC issues guidance on the impact of COVID-19 on research funded or supported by NIHR, Available from: https://www.nihr.ac.uk/news/dhsc-issuesguidance-on-the-impact-on-covid-19-onresearch-funded-orsupported-bynihr/24469.

Reynolds, D. L., Garay, J. R., Deamond, S. L., Moran, M. K., Gold, W. and Styra, R. 2008. Understanding, compliance and psychological impact of the SARS quarantine experience. Epidemiology and Infection, 136:997 - 1007.

Roy, D., Tripathy, S., Kar, S. K., Sharma, N., Verma S. K., and Kaushal, V. 2020. Study of knowledge, attitude, anxiety \& perceived mental healthcare need in Indian population during COVID-19 pandemic. Asian Journal of Psychiatry,
$51: 102083$.

Tanne, J. H. Hayasaki, E., Zastrow, M., Pulla, P., Smith, P. and Rada, A. G., Covid-19: 2020. How Doctors and Healthcare Systems Are Tackling Corona virus Worldwide, British Medical Journal, 18:368.

Taylor, M. R., Agho, K. E., Stevens, G. J. and Raphae,1 B. 2008. Factors influencing psychological distress during a disease epidemic: data from Australia's first outbreak of equine influenza. BMC Public Health, 8:347.

UNESCO, 2020. COVID-19, Educational Disruption and Response, UNESCO, Available from:https://en.unesco.org/themes/educati on-emergencies/coronavirus-school closures.

WHO, 2020a. Corona virus Disease 2019 (COVID-19) Situation Report-46. URL https://www.who.int/docs/defaultsource/coronaviruse/situationreports/20200306-sitrep-46

WHO, 2020b. Rolling Updates on Corona virus Disease (COVID-19). URL https://www.who.int/emergencies/diseases /novel-coronavirus-2019/events-as-they happen.

World Economic Forum, 2020. This is how corona virus could affect the travel and tourism industry. Available from: https://www. weforum.org/agenda/2020/03/worldtravel-coronavirus-covid19-jobspandemictourism- aviation/.

\section{How to cite this article:}

Nayak, D. N., R. Kumar and Savalia, C. V. 2020. The Socio-economic Impacts of the COVID19 Pandemic: A Review. Int.J.Curr.Microbiol.App.Sci. 9(11): 562-566. doi: https://doi.org/10.20546/ijcmas.2020.911.069 